\title{
Effect of Intra and Inter Row Spacing on Yield, Yield Components and Growth Parameter of Hybrid Maize at Mettu, South Western Ethiopia
}

\author{
Tolossa Ameyu Gizawu Tesfaye \\ Ethiopian Institute of Agricultural Research; Jimma Agricultural Research Center \\ P.O Box 192, Jimma, Ethiopia
}

\begin{abstract}
Effect of intra- and inter-row spacing on growth, yield components and grain yield of maize was investigated at Mettu, South Western Ethiopia in 2016, to determine the optimum inter- and intra-row spacing of hybrid maize for maximum yield and yield components. The experimental design was a randomized complete block design in split plot arrangement with three replications. Main plot were inter row spacing of $65 \mathrm{~cm}, 75 \mathrm{~cm}$ and $85 \mathrm{~cm}$. Subplot were intra row spacing of $15 \mathrm{~cm}, 20 \mathrm{~cm}, 25 \mathrm{~cm}$, and $30 \mathrm{~cm}$. Significant interaction effect of inter- and intra-row spacing was observed for leaf area, but for other traits only the main effect of inter- and intra-row spacing was significant. The highest grain yield $\left(9609.2\right.$ and $\left.9618.9 \mathrm{~kg} \mathrm{ha}^{-1}\right)$ was obtained at $15 \mathrm{~cm}$ intra row spacing and $65 \mathrm{~cm}$ inter row spacing respectively, while the lowest $\left(8618.5\right.$ and $\left.8808.2 \mathrm{~kg} \mathrm{ha}^{-1}\right)$ grain yield was obtained from $30 \mathrm{~cm}$ intra row spacing and $85 \mathrm{~cm}$ inter row spacings respectively. In conclusion and recommendation, since this experimental data was one season and location data, the comprehensive recommendation could be drawn by investigating data of more locations over years for this hybrid maize.
\end{abstract}

Keywords: Maize hybrid, intra row spacing, inter row spacing

DOI: $10.7176 / \mathrm{JEES} / 10-1-03$

Publication date: January $31^{\text {st }} 2020$

\section{Introduction}

Maize (Zea mays L.) is considered as a one of the most important strategic cereal food crops in Ethiopia and the world. It is among the leading cereals in production along with rice and wheat. Normal maize grain has greater nutritional value as it contains $72 \%$ carbohydrate, $8.8 \%$ protein, $2.15 \%$ fiber and $2.33 \%$ ash (Shah et al., 2015). It is a good source of carbohydrates, fat, protein and some important vitamins (B6, A and E) and minerals (magnesium, potassium and phosphorus), but deficient in essential amino acids viz., lysine and tryptophan that reduces its biological value (Mbuya et al., 2011). The amount of these deficient amino acids has been increased by incorporating opaque-2 gene in quality protein maize (QPM) (Bisht et al., 2012). It produces 70-100\% more of lysine and tryptophan than the most modern varieties of tropical maize (Vivek et al., 2008).

Twumasi-Afriyie et al. (2016) reported that an estimated area of one million ha of land in Sub Saharan Africa (SSA) was under QPM production in 2015. Research on QPM is of recent history in Ethiopia and the work was started by testing introduced CIMMYT (International Maize and Wheat Improvement Center) QPM pools and populations in 1980 (Leta et al., 2001). To intensification grain corn production per unit area of maize in Ethiopia, it must be resolute the appropriate maize hybrids (BHQPY545) at both row and hill spacing to exploit its productivity. Maize hybrid (BHQPY545) agronomic characters may be affected due to row width and hill spacing that affect production per unit area.

The low yield of crops has been partly attributed to inappropriate plant density, planting time, and pest pressure (weeds, diseases and insect pests) (Gebremichael, 2011). The establishment of an adequate plant density is critical for utilization of available growth factors such as water, light, nutrients and carbon-dioxide and to maximize grain yield. Decreasing the distance between neighbor rows at any particular plant population has several potential advantages. It reduces competition among plants within rows for light, water and nutrients due to a more equidistant plant arrangement (Olson \& Sander, 1988; Porter et al., 1997). Growth and grain yield of maize is more affected by variations in hill spacing than other members of the grass family. Too wide spacing leads to low plant density per unit area and reduces ground cover, whereas too narrow spacing is related to intense competition between plants for growth factors (Singh et al., 2004). It is observed that spacing of crop is important for good yield. Harper (1983) reported that with non-tillering (branching) crop varieties, higher yield per plant will give high total yield per hectare once the optimum population is not exceeded. Plant population plays an important role as it is one of the most important yield contributing characters (Rafei M.2009).

Recently, (Attia, A. et al 2012 ) reported that maize plants sown in line having $(60 \mathrm{~cm})$ row to row distance had, heavier 1000 grains weight and highest grain yield. Leilah A.A. et al (2013) point out that planting maize in ridges 80 or $90 \mathrm{~cm}$ apart produced the highest values of yield and yield components and planting maize in ridges $70 \mathrm{~cm}$ apart gave the lowest values of yield and growth parameters. According to the recent investigation, (Gobeze, $\mathrm{Y}$ et al 2012) the highest number of the ear, stem diameter and cob length were recorded at 8 plants $/ \mathrm{m} 2$, while the 
highest values of plant height were recorded at 12 plants $/ \mathrm{m} 2$. Similarly, Darwich M. (2009) reported that increasing maize distance between rows from 60 to 70 and $80 \mathrm{~cm}$ lead to a significant increase in growth character, grain and its components due to better interception and utilization of solar radiation and the increase in photosynthetic processes. Population above the optimum has resulted in lodging that has caused a reduction in maize production. Sharifai A, et al.,(2012) reported that increase in intra-row spacing from 20 to $25 \mathrm{~cm}$ significantly increased number of row per cob, cob diameter, 100-grain weight and grain yield. The earlier crop cover provided by smaller / narrow intra row is instrumental to enhance soil protection, diminishing water runoff and soil erosion (Mannering \& Johnson, 1969; Sangoi et al., 1998). Therefore, this experiment was conducted to determine growth and yield performance of maize hybrid (BHQPY545) under different intra and inter row spacing at Mettu, south western of Ethiopia.

\section{MATERIALS AND METHOD}

Description of the Study Area

The experiment was conducted at Mettu, during the 2015/16 growing seasons. It is located at $600 \mathrm{~km}$ away from Addis Ababa in Iluabbabora Zone of the Oromia Regional National State. It is located at latitude $8^{\circ} 19^{\prime} 0^{\prime \prime} \mathrm{N}$ longitude $35^{\circ} 35^{\prime} 0^{\prime \prime} \mathrm{E}$ at an altitude of $1567 \mathrm{~m}$.a.s.l and it has been characterized as Tepid to cool humid mid highlands with annual rainfall distribution pattern of $1835 \mathrm{~mm} /$ annum. The mean annual temperature ranges from 12 to $27{ }^{\circ} \mathrm{C}$. The predominant soil type is Nitisol.

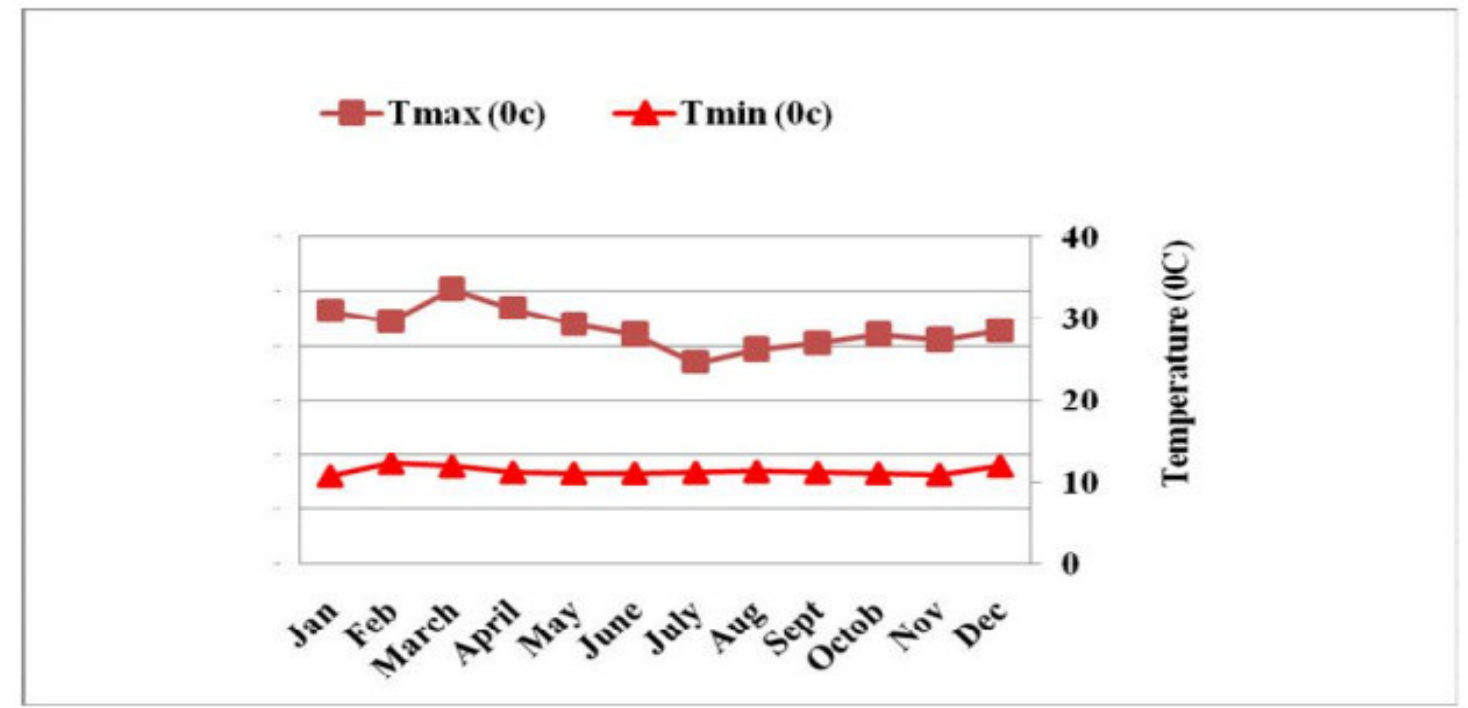

Figure: 1. Mean minimum and maximum temperatures $\left({ }^{\circ} \mathrm{C}\right)$ of Mettu during 2016

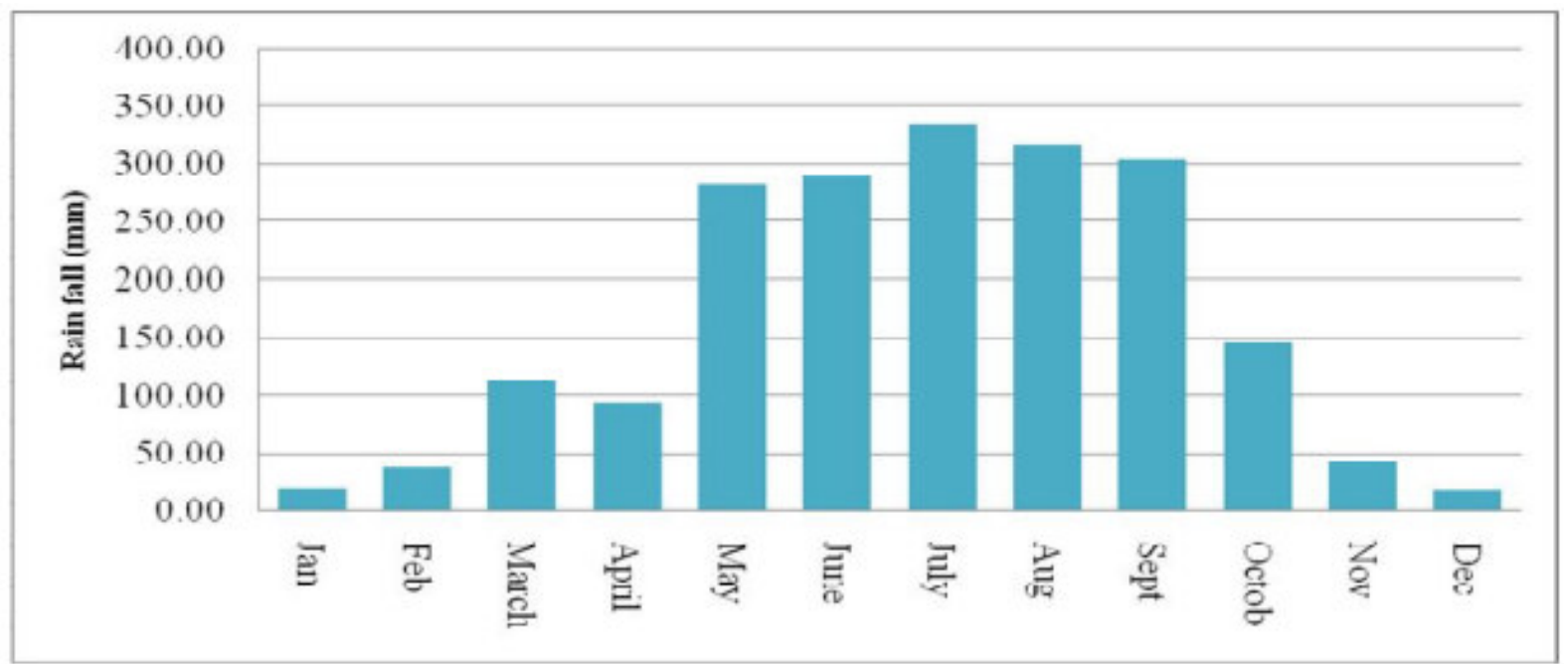

Figure: 2. Monthly total rainfall (mm) of Mettu during crop growth period in 2016 Source: Jimma Agricultural Research, Mettu Sub center Agro meteorology Department 


\section{Treatments, Experimental Design and Procedures}

The treatments comprised of two factors namely: intra and inter row spacing. The experimental design used was split plot arranged in randomized complete blocks. Three inter row spacing $(65,75$ and $85 \mathrm{~cm})$ were used as the main plot and four intra row spacing $(15,20,25$ and $30 \mathrm{~cm})$ were used as sub plot treatments. Each treatment was replicated three times. The total number of treatment was 12 and there were 36 total observations in this experiment. Each sub plot consisted of six rows and four harvestable rows. Individual plot rows were $6 \mathrm{~m}$ long. A conventional tillage method was used to prepare the soil by plowing three times. Two seeds were placed per hill to ensure the desired stand in each treatment and thinned to one plant. Thinning was done at 3-4 leaves stage.

Medium maturing maize variety BHQPY545 was used for the study. It was released by Bako Agricultural Research Centre through the National Maize Research Program in 2008. It performs well in agro-ecology of 1000-2000 m.a.s.l with rainfall of 1000-1200 mm. The seed of BHQPY 545 maize variety was obtained from Jimma Agricultural Research Center for the experiment. Nitrogen were applied in split form at 30 and 65 days after emergence at the rate of $92 \mathrm{~kg} / \mathrm{ha}$ and Phosphorus were applied during planting day at rates of $69 \mathrm{~kg} / \mathrm{ha}$, based on $\mathrm{N}$ and P2O5 recommendation for maize on Nitisols of Jimma area (92 kg ha-1 N and $\left.69 \mathrm{~kg} \mathrm{ha}^{-1} \mathrm{P} 2 \mathrm{O} 5\right)$ (Wakene et al., 2011).

Table: 1 Treatment Combinations and Descriptions

\begin{tabular}{llll}
\hline No & Inter * Intra rows spacing & Area of one plant & Number of plants per hectare \\
\hline 1 & $85 \mathrm{~cm}^{*} 15 \mathrm{~cm}$ & $0.1275 \mathrm{~m}^{2}$ & 78431.37 \\
2 & $85 \mathrm{~cm}^{*} 20 \mathrm{~cm}$ & $0.170 \mathrm{~m}^{2}$ & 58823.53 \\
3 & $85 \mathrm{~cm}^{*} 25 \mathrm{~cm}$ & $0.2125 \mathrm{~m}^{2}$ & 47058.80 \\
4 & $85 \mathrm{~cm}^{*} 30 \mathrm{~cm}$ & $0.2550 \mathrm{~m}^{2}$ & 39215.68 \\
5 & $75 \mathrm{~cm}^{*} 15 \mathrm{~cm}$ & $0.1125 \mathrm{~m}^{2}$ & 88888.89 \\
6 & $75 \mathrm{~cm}^{*} 20 \mathrm{~cm}$ & $0.150 \mathrm{~m}^{2}$ & 66666.66 \\
7 & $75 \mathrm{~cm}^{*} 25 \mathrm{~cm}$ & $0.1875 \mathrm{~m}^{2}$ & 53333.33 \\
8 & $75 \mathrm{~cm}^{*} 30 \mathrm{~cm}$ & $0.2250 \mathrm{~m}^{2}$ & 44444.44 \\
9 & $65 \mathrm{~cm}^{*} 15 \mathrm{~cm}$ & $0.0975 \mathrm{~m}^{2}$ & 102564.0 \\
10 & $65 \mathrm{~cm}^{*} 20 \mathrm{~cm}$ & $0.130 \mathrm{~m}^{2}$ & 76923.00 \\
11 & $65 \mathrm{~cm}^{*} 25 \mathrm{~cm}$ & $0.1625 \mathrm{~m}^{2}$ & 61538.40 \\
12 & $65 \mathrm{~cm}^{*} 30 \mathrm{~cm}$ & $0.195 \mathrm{~m}^{2}$ & 51281.99 \\
\hline
\end{tabular}

\section{Data Collection and Measurements}

Stem diameter (girth): it was measured at $50 \mathrm{~cm}$ from the ground level on five randomly selected plants using caliper. Internodes length $(\mathrm{cm})$ : it was measured at $50 \mathrm{~cm}$ from the ground level of the first node on five randomly selected plants. Plant height $(\mathrm{cm})$ : it was measured at ground level to terminal stem using measuring stick at the point where the tassel starts branching from five randomly selected plants. Ear height $(\mathrm{cm})$ : it was measured at ground level to the final ear using measuring stick from five randomly selected plants. Number of ear per plant: it was obtained by counting total number of ears in each plot and divided to total number of plant stand harvested. Number of cobs harvested: it was obtained by counting total number of ears in each plot at harvesting.

Hundred Seed weight $(\mathrm{g})$ : ears were selected randomly from five plants and hundred seed weight was measured by counting a hundred seeds using a seed counter and weighed it using sensitive balance at harvest and adjusted at $12.5 \%$ moisture. Grain yield $\left(\mathrm{kg} \mathrm{ha}^{-1}\right)$ : grain yield per plot was recorded using electronic balance and then adjusted to $12.5 \%$ moisture and converted to hectare basis.

\section{Statistical Analysis}

The data was subjected to analysis of variance (ANOVA) using Statistical Analysis System (SAS Institute, 2012) 9.3 Version software using proc GLM procedure. Duncan's multiple range tests and LSD was used to separate significantly differing treatment means after treatment effects were found significant at $\mathrm{P} \leq 0.05$.

\section{RESULTS AND DISCUSSION}

There were significant $(\mathrm{p} \leq 0.05)$ and highly significant differences $(\mathrm{p} \leq 0.01)$ among intra and inter rows for all growth, yield and yield components, that is plant height, ear height, girth, sterile number, number of ear per plant and yield (Table 2$)$. The interaction of intra row *inter row was no significant at $(\mathrm{p} \leq 0.05)$ for all growth, yield and yield components, except only for leaf area of the plant (Table 2). 
Table 2. Mean squares of intra row, inter row, and intra * inter row interaction for different trait at Mettu Mean square

\begin{tabular}{llllll}
\hline Parameters & Inter row & Error (a) & Intra row & inter*intra row & Grand mean \\
\hline Yield & $2312313.179^{* *}$ & 362415.39 & $1530796.15^{*}$ & $456453.91^{\mathrm{ns}}$ & 9116.289 \\
Plant height & $259.195^{* *}$ & 25.796 & $1632.185^{* *}$ & $11.61^{\mathrm{ns}}$ & 258.06 \\
Ear height & $361.08^{* *}$ & 39.26 & $1389.21^{* *}$ & $35.379^{\mathrm{ns}}$ & 146.25 \\
Girth & $0.128^{\mathrm{ns}}$ & 0.023 & $0.0988^{*}$ & $0.0052^{\mathrm{ns}}$ & 2.643 \\
Sterile number & $13.36^{*}$ & 3.640 & $81.850^{* *}$ & $1.990^{\mathrm{ns}}$ & 2.778 \\
Number of ear & $0.0318^{*}$ & 0.008 & $0.2980^{* *}$ & $0.0056^{\mathrm{ns}}$ & 1.579 \\
\hline
\end{tabular}

$*$ And $* *=$ significant at $5 \%$ and $1 \%$ significance levels, respectively; NS= Non-Significant.

Plant height: Plant height was significantly affected by intra and inters row spacing of BHQPY545 maize hybrid. The tallest plant height $(274.55 \mathrm{~cm})$ was measured at $15 \mathrm{~cm}$ intra rows, with regard to the effects of interrow spacing, the maximum plant height $(263.16 \mathrm{~cm})$ was recorded at narrow inter-row spacing of $65 \mathrm{~cm}$, while the shortest $(243.77$ and $254.08 \mathrm{~cm})$ plant height were measured at $30 \mathrm{~cm}$ intra rows and $85 \mathrm{~cm}$ inter rows respectively. There were differences among intra and inter row spacing in plant height and plant heights increased with decreases in intra and inter row spacing and the tallest plants were measured at $15 \mathrm{~cm}$ intra rows and $65 \mathrm{~cm}$ inter row spacing (Table 3). The increase in the plant height at narrowest spacing may be due to strong competition among the plants for light.

Higher plant height at narrow spacing could also be explained that when the plants are sown closely, their stems are shaded from light resulting in accumulation of auxin (a growth hormone) that stimulates cell division and elongation of internodes, thereby increase in height. While, in widely spaced plants, auxin destruction by light occurs resulting in plants being shorter in height (Mureithi et al., 2012). This result is in line with (Shamsi and Kobraee) who found taller plants were recorded at narrow spacing, while the shortest plants at wider spacing on mung bean. Konuskan (2000) found that plant height is increased with increases in plant density up to 10 plant $\mathrm{m}^{-2}$. Whereas Turgut (1975) reported there were no intra row spacing effects on plant height.

The main effects of inter row and intra-row spacing of maize hybrid on ear per plant and ear height at Mettu, during 2016 cropping seasons is given in Table 3. The highest number of ear per plant $(1.637$ and $1.808 \mathrm{~cm})$ was recorded at wider inter row spacings of $85 \mathrm{~cm}$ and also at $30 \mathrm{~cm}$ intra row spacings respectively, while the lowest number of ear per plant (1.37 and1.56) was found at $15 \mathrm{~cm}$ intra row spacing and $65 \mathrm{~cm}$ inter row spacing respectively (Table 3). The significant increase in number of ear per plant when spaced at wider inter spacing $85 \mathrm{~cm}$ and intra spacing $30 \mathrm{~cm}$ might be attributed to wider row and plant spacing and less inter or intra plant competition in the population as compared to narrow row and plant spacing. Wider inter-row $(85 \mathrm{~cm})$ and intrarow spacings $(30 \mathrm{~cm})$ increased the number of ear per maize plants, which might be increase in row and plant spacing decreased intra -specific competition and proper adjustment of plants in the field which facilitated more aeration and penetration of light which eventually caused increase ear per plant as compared to narrow spacing.

Ear initiation height: Ear initiation height was significantly $(\mathrm{P}<0.01)$ affected by the main effects of intra and inter-row spacing (Table 3). The narrower intra $(15 \mathrm{~cm})$ and inter-row $(65 \mathrm{~cm})$ spacing gave significantly taller ear height $(161.55$ and $152.16 \mathrm{~cm})$ than wider intra and inter row spacing of $30 \mathrm{~cm}$ and $85 \mathrm{~cm}$. Ear height was consistently decreased as spacing of inter-rows increased from $65 \mathrm{~cm}$ to $85 \mathrm{~cm}$ and intra rows from $15 \mathrm{~cm}$ to $30 \mathrm{~cm}$. The increase in Ear height at narrower inter and intra-row spacing might be due to comparatively low solar interception through crop canopy at narrow spacing (high plant density). Competition for light might be responsible for increase in ear and inter node height due to closer intra-row spacing and this might have resulted in longer internodes. This result agrees with Miko and Manga (2008) reported that maize ear height was significantly affected by inter-row spacing and $50 \mathrm{~cm}$ inter-row spacing was observed to give significantly higher plant height than $75 \mathrm{~cm}$. 
Table 3 the main effects of inter and intra row spacing on plant height, ear per plant and ear initiation height of quality protein maize at Mettu, 2016

\begin{tabular}{lccc}
\hline & plant height $(\mathrm{cm})$ & ear $/$ plant & ear height $(\mathrm{cm})$ \\
\hline Intra row spacing & & $1.375^{\mathrm{d}}$ & $161.55^{\mathrm{a}}$ \\
\hline $15 \mathrm{~cm}$ & $274.55^{\mathrm{a}}$ & $1.516^{\mathrm{c}}$ & $150.66^{\mathrm{b}}$ \\
$20 \mathrm{~cm}$ & $262.66^{\mathrm{b}}$ & $1.615^{\mathrm{b}}$ & $139.11^{\mathrm{c}}$ \\
$25 \mathrm{~cm}$ & $251.22^{\mathrm{c}}$ & $1.808^{\mathrm{a}}$ & $133.66^{\mathrm{c}}$ \\
$30 \mathrm{~cm}$ & $243.77^{\mathrm{d}}$ & $*^{\mathrm{a}}$ & $* *$ \\
\hline Inter-rows spacing & $* *$ & & $152.16^{\mathrm{a}}$ \\
\hline $65 \mathrm{~cm}$ & & $1.560^{\mathrm{a}}$ & $145.25^{\mathrm{b}}$ \\
$75 \mathrm{~cm}$ & $263.16^{\mathrm{a}}$ & $1.540^{\mathrm{a}}$ & $141.33^{\mathrm{b}}$ \\
$85 \mathrm{~cm}$ & $256.91^{\mathrm{b}}$ & $1.637^{\mathrm{a}}$ & $\mathbf{1 4 6 . 2 5}$ \\
\hline Mean & $254.08^{\mathrm{b}}$ & $\mathbf{1 . 5 8 0}$ & $* *$ \\
Significant level & $\mathbf{2 5 8 . 0 5}$ & $\mathbf{N S}$ & $\mathbf{4 . 2 8 4}$ \\
\hline CV (\%) & $* *$ & $\mathbf{5 . 6 9 7}$ & $\mathbf{1 . 9 6 8}$ \\
\hline
\end{tabular}

Means within a column followed by the same letter(s) are not significantly different at $\mathrm{p}<0.05$ (LSD). $\mathbf{C V}=$ Coefficient of variation

Stem girth/diameter: Stem girth/diameter of maize hybrid was significantly affected by main effect of intra rows and not affected by inters row spacing. The highest stem diameter $(2.74 \mathrm{~cm})$ was recorded at $30 \mathrm{~cm}$ intra row spacing which was statistically at par with 20 and $25 \mathrm{~cm}$ intra row spacings and the lowest stem diameter $(2.49 \mathrm{~cm})$ was determined at $15 \mathrm{~cm}$ intra row spacing (Table 4). Kunuskan, O, (2000) reported that stem diameter were lower in higher plant densities as a consequence of interplant competitions.

Grain yield: Grain yield is the end result of many complex morphological and physiological processes occurring during the growth and development of the crop. The highest grain yield $\left(9609.2 \mathrm{~kg} \mathrm{ha}^{-1}\right)$ was observed from the narrower intra-row spacing $(15 \mathrm{~cm})$, which was statistically at par with the yield of 20 and $25 \mathrm{~cm}$ intrarow spacings (Table 4$)$. The lowest $\left(8618.5 \mathrm{~kg} \mathrm{ha}^{-1}\right)$ grain yield was recorded with the widest intra-row spacing $(30 \mathrm{~cm})$. With regard to the effects of inter-row spacing, the highest grain yield $\left(9618.9 \mathrm{~kg} \mathrm{ha}^{-1}\right)$ was recorded at narrow inter-row spacing of $65 \mathrm{~cm}$. The lowest $\left(8808.2 \mathrm{~kg} \mathrm{ha}^{-1}\right)$ grain yield was recorded with the widest interrow spacing $(85 \mathrm{~cm})$.Within the range of row spacing evaluated in the trial, there was an enhancement in grain yield that varied from 697.2 to $810.7 \mathrm{~kg} /$ ha depending on row spacing reduction from $30 \mathrm{~cm}$ to $15 \mathrm{~cm}$. This might be because of increased the spacing reduced due to superior yield in the case of high plant populations over that of low plant population of hybrid maize. The yield increment promoted by the use of narrow rows may be related to a higher interception of solar radiation and greater radiation use efficiency.

Table 4 the main effects of inter and intra row spacing on grain yield, stem girth, number of sterile plants and internodes length of quality protein maize at Mettu, 2016

\begin{tabular}{|c|c|c|c|c|}
\hline Yield $(\mathrm{kg} / \mathrm{ha})$ & Stem girth $(\mathrm{cm})$ & number of Sterile & Internodes length $(\mathrm{cm})$ & \\
\hline \multicolumn{5}{|l|}{ Intra rows } \\
\hline $15 \mathrm{~cm}$ & $9609.2^{\mathrm{a}}$ & $2.49^{b}$ & $7.11^{\mathrm{a}}$ & $15.20^{\mathrm{a}}$ \\
\hline $20 \mathrm{~cm}$ & $9217.6^{\mathrm{a}}$ & $2.66^{\mathrm{a}}$ & $2.44^{\mathrm{b}}$ & $14.40^{\mathrm{a}}$ \\
\hline $25 \mathrm{~cm}$ & $9019.8^{a}$ & $2.67^{\mathrm{a}}$ & $1.22^{\mathrm{bc}}$ & $13.33^{\mathrm{b}}$ \\
\hline \multirow[t]{2}{*}{$30 \mathrm{~cm}$} & $8618.5^{\mathrm{b}}$ & $2.74^{\mathrm{a}}$ & $0.33^{\mathrm{c}}$ & $12.77^{\mathrm{b}}$ \\
\hline & $*$ & $*$ & $* *$ & $* *$ \\
\hline \multicolumn{5}{|l|}{ Inter-rows } \\
\hline $65 \mathrm{~cm}$ & $9618.9^{2}$ & $2.53^{\mathrm{a}}$ & $3.92^{\mathrm{a}}$ & $14.05^{\mathrm{a}}$ \\
\hline $75 \mathrm{~cm}$ & $8921.7^{\mathrm{t}}$ & $2.68^{\mathrm{a}}$ & $2.58^{\mathrm{ab}}$ & $14.00^{\mathrm{a}}$ \\
\hline $85 \mathrm{~cm}$ & $8808.2^{\mathrm{b}}$ & $2.72^{\mathrm{a}}$ & $1.83^{\mathrm{b}}$ & $13.73^{\mathrm{a}}$ \\
\hline Mean & 9116.27 & 2.64 & 2.78 & 13.93 \\
\hline Significant level & $* *$ & NS & $*$ & NS \\
\hline CV (\%) & 6.60 & 5.78 & 68.67 & 6.41 \\
\hline
\end{tabular}

Means within a column followed by the same letter(s) are not significantly different at $\mathrm{p}<0.05$ (LSD). $\mathbf{C V}=$ Coefficient of variation

Leaf area: The main effects of both intra and inter-row spacing on leaf area were significant $(\mathrm{P}<$ $0.05)$ and also the interaction effect of intra and inter-row spacing was significant $(\mathrm{P}<0.05)$. The highest leaf area per plant $\left(1298.48 \mathrm{~cm}^{2}\right)$ was recorded at inter-row and intra row spacing of $75^{*} 30 \mathrm{~cm}$, while the lowest $\left(1147.67 \mathrm{~cm}^{2}\right)$ was at $65^{*} 15 \mathrm{~cm}$ inter and intra row spacing (Table 5). In general leaf area per plant was increased with increasing inter and intra-row spacing (from $65^{*} 15 \mathrm{~cm}$ to $85^{*} 30 \mathrm{~cm}$ ). The higher leaf area per plant in the wider inter-row spacing and intra-row spacing might be due to more availability of growth factors and 
better penetration of light, consequently increased number of leaves produced and the size of individual leaves in plants at wider row spacing. This result in agreement with Sangoi et al. (2001) showed that higher leaf area of maize $\left(7258 \mathrm{~cm}^{2}\right)$ was attained at row spacing of $75 \mathrm{~cm}$ than at $50 \mathrm{~cm}$ row spacing $\left(6118 \mathrm{~cm}^{2}\right)$.

Table 5: Interaction effect of intra and inter row spacing on leaf area $\left(\mathrm{cm}^{2}\right)$ of maize hybrid at Mettu during 2016

\begin{tabular}{ccccc}
\hline Intra row spacing $(\mathrm{cm})$ & \multicolumn{4}{c}{ Inter row spacing $(\mathrm{cm})$} \\
\cline { 2 - 5 } & $65 \mathrm{~cm}$ & $75 \mathrm{~cm}$ & $85 \mathrm{~cm}$ & Mean \\
\hline $30 \mathrm{~cm}$ & $1256.93^{\mathrm{abc}}$ & $1298.48^{\mathrm{a}}$ & $1263.40^{\mathrm{abc}}$ & 1272.94 \\
$25 \mathrm{~cm}$ & $1250.13^{\mathrm{abc}}$ & $1215.13^{\mathrm{bcd}}$ & $1251.60^{\mathrm{abc}}$ & 1238.95 \\
$20 \mathrm{~cm}$ & $1221.0^{\mathrm{abcd}}$ & $1291.67 \mathrm{ab}$ & $1219.33^{\mathrm{bcd}}$ & 1244.00 \\
$15 \mathrm{~cm}$ & $1147.67^{\mathrm{d}}$ & $1201.60 \mathrm{~cd}$ & $1232.67^{\mathrm{abc}}$ & 1193.98 \\
\hline Mean & $\mathbf{1 2 1 8 . 9 3}$ & $\mathbf{1 2 5 1 . 7 2}$ & $\mathbf{1 2 4 1 . 7 5}$ \\
\hline LSD & $\mathbf{7 8 . 0}$ & $\mathbf{3 . 7 7}$ \\
\hline CV & \multicolumn{5}{c}{} \\
\hline
\end{tabular}

Means within a column followed by the same letter(s) are not significantly different at $\mathrm{p}<0.05$ (LSD). $\mathbf{C V}=$ Coefficient of variation $\mathrm{LSD}=$ list significant difference

Stalk lodging, Seed weight and bare cob: The main effect of intra and inter row spacing had no significant effect on hundred seed weight, while main effect of intra row spacing had a significant effect on number of bare cobs and inter row spacing had a significant effect on stalk lodging percentage of maize hybrid. However, the interaction was not significant. The highest number of bare cobs $(14.22)$ was obtained at narrow $(15 \mathrm{~cm})$ intra row spacing, but was not statistically different from $20 \mathrm{~cm}$ intra row spacing (Table 6), while the lowest number of bare cobs (5) was recorded at the wider $(30 \mathrm{~cm})$ intra row spacing. This might be due to higher population $\left(15^{*} 65 \mathrm{~cm}\right)$, have the adverse effect on the grain yield filling was noticed due to intense interplant competition to fulfill the grain yield and floral abortion. The young kernel abortion immediately after fertilization is due to a lower supply of carbon and nitrogen to the ear due to high compition among the plant which bring the cobs left unfilled or bare cobs (Liu et al., 2015).

Similarly, the highest lodging percentage $(10.362 \%)$ was obtained at $65 \mathrm{~cm}$ inter row spacing, (Table 6), while the lowest $(4.86 \%$ ) was recorded at the wider inter row spacing, but was not statistically different from $75 \mathrm{~cm}$ inter row spacing (Table 6). Population above the optimum has resulted in lodging that has caused a reduction in maize production. This might be due to reducing intra row spacing led to thinner plants, which were also characterized by a taller plant height, which displayed a lodging tendency throughout the growing period. High lodging percentages at closest inter row spacing might be due to higher plant competition for available resources like solar radiation, nutrients, water, air and space which led to thinner plants and falling of maize.

Table 6: Main effect of intra and inter row spacing on hundred seed weight (g), bare cob and lodging of hybrid maize at Mettu during 2016

\begin{tabular}{cccc}
\hline Intra row spacing $(\mathrm{cm})$ & HSW $(\mathrm{g})$ & Bare cob(number) & Lodging $(\%)$ \\
\hline $15 \mathrm{~cm}$ & $30.467^{\mathrm{a}}$ & $14.22^{\mathrm{a}}$ & $4.11^{\mathrm{a}}$ \\
$20 \mathrm{~cm}$ & $30.322^{\mathrm{a}}$ & $11.33^{\mathrm{ab}}$ & $6.91 \mathrm{a}$ \\
$25 \mathrm{~cm}$ & $29.929^{\mathrm{a}}$ & $7.88^{\mathrm{bc}}$ & $8.83 \mathrm{a}$ \\
$30 \mathrm{~cm}$ & $29.189^{\mathrm{a}}$ & $5.00^{\mathrm{c}}$ & $7.48 \mathrm{a}$ \\
\hline Mean & $\mathbf{2 9 . 9 2 8}$ & $\mathbf{9 . 6 1}$ & $\mathbf{6 . 8 3}$ \\
LSD & $\mathbf{N S}$ & $\mathbf{5 . 1}$ & $\mathbf{N S}$ \\
\hline Inter row spacing $(\mathrm{cm})$ & & & $10.362^{\mathrm{a}}$ \\
\hline $65 \mathrm{~cm}$ & $29.151^{\mathrm{a}}$ & $10.5^{\mathrm{a}}$ & $5.270^{\mathrm{b}}$ \\
$75 \mathrm{~cm}$ & $30.131^{\mathrm{a}}$ & $9.42^{\mathrm{a}}$ & $4.863^{\mathrm{b}}$ \\
\hline Mean & $30.44^{\mathrm{a}}$ & $8.83^{\mathrm{a}}$ & $\mathbf{6 . 8 3}$ \\
LSD & $\mathbf{2 9 . 9 1}$ & $\mathbf{9 . 5 8}$ & $\mathbf{4 . 6 8 *}$ \\
CV & $\mathbf{N S}$ & $\mathbf{N S}$ & $\mathbf{8 . 1}^{*}$ \\
\hline
\end{tabular}

Means within a column followed by the same letter(s) are not significantly different at $\mathrm{p}<0.05$ (LSD). $\mathbf{C V}=$ Coefficient of variation, $\mathrm{LSD}=$ list significant difference

\section{Conclusion and recommendation}

Appropriate row and plant spacing is quite important to come up with profitable and sustainable maize production and productivity. In view of this, an experiment was conducted to determine the effect of intra and inter-row spacing on the yield and yield components of maize. This study indicated that growth and yield components plant height, ear height, stem diameter, leaf area, and number of ear per plant, 100-seed were significantly influenced by only main effect of intra and inter row spacing, except leaf area which was affected by interaction of intra and inters row spacings. The highest grain yield (9609.2 and $\left.9618.9 \mathrm{~kg} \mathrm{ha}^{-1}\right)$ was obtained at narrow intra 
row $(15 \mathrm{~cm})$ spacing and narrow $(65 \mathrm{~cm})$ inter row spacing respectively, while the lowest $(8618.5$ and $8808.2 \mathrm{~kg}$ $\mathrm{ha}^{-1}$ ) grain yield was obtained from wider $(30 \mathrm{~cm})$ intra row spacing and wider $(85 \mathrm{~cm})$ inter row spacings respectively. In conclusion and recommendation, since this experimental data was one season and location data, the comprehensive recommendation could be drawn by investigating data of more locations over years for this hybrid maize.

\section{References}

Abuzar M.R., G.U. Sadozai, M.S. Baloch, A.A. 2011 Baloch, I.H. Shah, T. Javaid and N. Hussain, "Effect of plant population densities on yield of maize". Journal of Animal and Plant Science, , 21, 692-695.

Attia A.N, S.A. El-Moursy, G.M.A. Mahgoub, and M.M.B. Darwich, 2012 "Effect of ridge spacing and plant density for row maize hybrids" Journal Agriculture Science Mansoura University,

Bisht, A.S., Bhatnagar, A., Pal, M.S., Singh, V., 2012. Growth dynamics, productivity and economics of Quality Protein Maize (Zea mays L.) under varying plant density and nutrient management practices. Madras Agricultural Journal, 99 (3): 73-76.

Darwich M.M.B, 2009 "Effect of row spacing and plant density on grow the yield and its component of some new maize hybrids. M.Sc. Thesis, , Fac. of Agric. Mansoura University, Egypt.

Gobeze Y.L. , G. Michaelceronio and L.D.V. Rensburg, 2012 "Effect of row spacing and plant density on yield and yield component of maize (Zea maysL.) under irrigation" Journal of Agriculture Science and Technology, 2B, 263-271.

Kunuskan, O, 2000. Effects of plant density on yield and yield related characters of some maize hybrids grown in hatay conditions as a second crop. Msc thesis, science institute M.K.U., pp.71

Leilah A.A., S.E. El-Kalla, K.A. El-Douby and A.M.K. Abd Rabboh,2013 "Maximizing corn productivity through some modern farming systems. Journal Plant Production Mansoura University, 4, 561-575

Leta, T., Mosisa, W., Gelana, S., Jemal, A., Hadji,T., Sewagegne, T. and Twumasi-Afriyie, S.,2001. Enhancing the Contribution of Maize to Food Security in Ethiopia. pp.39-45.

Liu, T., Gu, L.,Dong, S.,Zhang, J., Liu, P., Zhao, B., 2015.Optimum leaf removal increases canopy apparent photosynthesis, 13C-photosynthate distribution and grain yield of maize crops grown at high density. Field Crops Res.170, 32-39.

Mbuya, K, Nkongolo, K.K. and Kalonji-Mbuyi, A., 2011. Nutrition analysis of quality protein maize selected for agronomic characteristics in a breeding program. Int. J. Plant Breed. Genet., 2(11): 325-332.

Miko, S. and A. A. Manga, 2008. Effect of intra-spacing and nitrogen rates on growth and yield of sorghum (Sorghum bicolor L.) Var. ICSV 400. Journal of Agronomy, 4 (2): 66-73.

Muhammad, S. Hassan, A. Shah and F. Ullah, 2016 "Effect of row spacing and methods of sowing on the performance of maize" Austin Food Science. 1, 1-4.

Mureithi D.M., Onyango M.O., Jeruto P., Gichimu B.M. 2012. Response of French bean (Phaseolus Vulgaris L.) to intra-row spacing in Moseno Division, Kenya.Journal of applied science, 12(1): 96-100.

Rafei M. 2009 Infuence of tillage and plant density on mung bean. Am Eur J Sustain Agric. 3:877-80

Sangoi, L., M. Ender, A. Guidolin, M.L. de Almeida and P. C. Heberle, 2001. Influence of row spacing reduction on maize grain yield and yield components. Agronomy Journal, 36(6) 861-869,

Shah, T.R., Prasad, K. and Kumar, P., 2015. Studies on physicochemical and functional characteristics of asparagus bean flour and maize flour. pp. 103-105. In: Conceptual frame work and innovations in agroecology and food sciences. Krishi Sanskriti Publications, New Delhi.

Shamsi K, Kobraee S. Effect of plant density on the growth, yield and yield components of three soybean varieties under climatic conditions of Kermanshah, Iran. Anim Plant Sci J. 2009; 2(2):96-9.

Sharifai, A.I. M. Mahmud, B. Tanimu, and I.U. Abubakar,2012 "Yield and yield components of extra early maize (Zea mays L.) As influenced by intra row spacing, nitrogen and poultry manure rates" Bayero Journal of Pure and Applied Science, 5:113-122.

Turgut, I., 2000. Effects of plant populations and nitrogen doses on fresh ear yield and yield components of sweet corn (Zea Mays saccharata sturt.) grown under bursa conditions. Turk.J.Agric. For., 24:341-347.

Twumasi-Afriye, S., Palacios Rojas, N., Friesen, D., Teklewold, A., Gissa, D.W., De Groote, H. and Prasanna, B.M., 2016. Guidelines for the quality control of Quality Protein Maize seed and grain. 38p.

Vivek, B.S., Krivanek, A.F., Palacios-Rojas, N., Twumasi-Afriyie, S. and Diallo, A.O., 2008. Breeding Quality Protein Maize (QPM): Protocols for developing QPM cultivars. CIMMYT, Mexico. 50p 